\title{
PICTURES VERSUS LETTERS: WILLIAM WARBURTON'S THEORY OF GRAMMATOLOGICAL ICONOCLASM
}

Jan Assmann

The ancient Egyptians have always been held to be the paradigmatical or archetypal idolators, and the iconoclasm of the second commandment has always been understood as having been directed primarily against Egypt. Was not Egypt the nation out of which the Lord redeemed his people? Speaking of iconoclasm means to speak of anti-Egyptianism, of exodus, separation and rejection with regard to the world of images. The debate between Egyptian iconists and antiEgyptian or Biblical iconoclasts has many aspects. In the following paper I am choosing one of them for closer study, an aspect which as far as I can see has up to now received only very little attention: the grammatological aspect of iconoclasm. Since iconicity, writing and revelation are central topics within a dialogue I am entertaining with Moshe Barasch over many years, I dedicate this essay to him, to whom it owes so much inspiration.

The discovery of a manuscript of Horapollo's Hieroglyphica on the island of Andros in 1419 led to a linguistic and semiotic revolution. The ancient debate as to whether words referred to things and concepts 'by nature' (physei) or 'by convention' (thesei) which seemed to have been closed once and for all by Aristotle in favor of 'convention' was re-opened with the discovery of a writing system that was (mis)interpreted to refer 'by nature' to things and concepts. Due to this discovery, the linguistic debate between 'Platonists' and 'Aristotelians' turned into a debate on writing. But now, with regard to writing, it was no longer a question of either/or, that is, whether writing refers directly to things or indirectly to language, but a question of comparison and historical development. There were two principally different writing systems, presumably in use side by side in ancient Egypt, one referring to things and concepts "by nature", that is iconically, and the other one referring to concepts and sounds "by convention", that is by arbitrary signs. Ancient Egypt was held to be a culture that not only invented Hieroglyphs as a system of picture 
writing or natural signification but that also invented alphabetic writing as a system of conventional signification. ${ }^{1}$

The idea that ancient Egypt used two radically different scripts was based upon ancient tradition. Almost all of the Greek and Latin authors on Ancient Egypt, above all Herodotus and Diodorus, agreed that the Egyptians used two scripts, one called "Hieratic" or "Hieroglyphic" and the other one called "Demotic" or "Epistolic". The Hieratic or Hieroglyphic script was interpreted as sacred (hieros = sacred), inscriptional (glyph $=$ "carved" sign) and iconic, the Demotic or Epistolic script was interpreted as profane $($ demos $=$ common people), used for everyday communication (epistole $=$ correspondence) and aniconic, that is, alphabetic. All this corresponds closely to historical reality as far as modern Egyptology is able to reconstruct it except one detail: the equation of aniconic and alphabetic signs. The Egyptians distinguished between what they called "epistolary script" (zh r $\left.\breve{s}^{c} . t\right)$ and "divine speech" (md.t ntr). Epistolary script is what we call today "Demotic" and refers to the vernacular language; "divine speech" refers to the classical language and has a cursive form called "Hieratic" and an inscriptional and iconic form called "Hieroglyphic". If we concentrate on the outward appearance of the signs, we should distinguish three different scripts; if, however, we concentrate on the languages written by these scripts, we are dealing with two different scripts one of them occuring in a cursive and in an iconic form. The ancient authors, accordingly, speak partly of three and partly of two Egyptian scripts. The first to give an account of Egyptian digraphia is Herodotus. The most famous and influential description, however, is given by Diodorus:

Dittôn gàr Aiguptiois ónton grammáton, tà mèn demóde prosagoreuómena pántas manthánein, tà dè hierà kaloúmena

parà mèn toûs Aiguptiois mónous gignóskein

toùs hiereîs parà tôn patéron

en aporrhétois manthänontas,
The Egyptians use two different scripts:

one, called "demotic", is learned by all; the other one is called "sacred". This one is understood among the Egyptians exclusively by the priests who learn them from their fathers in the mysteries. ${ }^{2}$

${ }^{1}$ Concerning the grammatological discourse on hieroglyphs in early modernity see especially Liselotte Dieckmann, Hieroglyphics, St Louis 1970; Madeleine V. David, Le débat sur les écritures et l'hiéroglyphic aux XVIIe et XVIIIe siècle, Paris 1965. Erik Iversen, The Myth of Egypt and its Hieroglyphs in European Tradition, Copenhagen: Ced Gad Publ., 1961; repr. Princeton, 1993.

${ }^{2}$ Diodorus, bibl.hist., III.3,4. 
The existence of two different scripts is explained by a functional and social distinction: the distinction between the sacred and the profane, priests and laymen, secrecy and publicity. For the scholars of early modern Europe, it was more than plausible to link this situation of digraphia with what Heliodorus and other ancient authors described as the Egyptian "duplex philosophy", a vulgar or exoteric one and an exclusive or esoteric one, one for the priests and one for the people. Egyptian culture and its writing systems, therefore, became interesting for scholarship in two regards: first and foremost, because it offered a system of "natural signs", a "scripture of nature," a writing which would refer not to the sounds of language, but to the things of nature and to the concepts of the mind. Secondly, because it supplemented and contrasted this natural system with a conventional one and showed beyond any reasonable doubt, that picture writing or immediate signification was a matter of esotericism, mystery and the tradition of sacred knowledge whereas alphabetic writing was a matter of general and profane communication.

In this image of ancient Egyptian grammatology, there was thus a close connection between iconicity and sacredness. Religion, priesthood, and mystery used icons, while the alphabet dominated the state, administration, and the public domain. This association of picture writing, that is, the principle of immediate and natural signification, with the mysteries of Egyptian religion, gains an utmost importance for the debate which I am going to relate in the following pages. The sacredness of hieroglyphs was identified with the principle of immediate signification. Immediacy is the key word in this context: the signs conveyed their meaning without mediation either by language or by a conventional code. To quote Ralph Cudworth's definition: "The Egyptian hieroglyphicks were figures not answering to sounds or words, but immediately representing the objects and conceptions of the mind." 3 This interpretation of the Egyptian hieroglyphs was based particularly on a famous passage in Plotinus which reads as follows:

The wise men of Egypt, I think, also understood this, either by scientific knowledge or innate knowledge, and when they wished to signify something wisely, did not use the form of letters which follow the order of words and propositions and imitate sounds and the enunciations of philosophical statements, but by drawing images [agalmata] and inscribing

${ }^{3}$ Ralph Cudworth, The True Intellectual System of the Universe: the First Part, wherein All the Reason and Philosophy of Atheism is Confuted and its Impossibility Demonstrated (1st ed. London: 1678; 2nd ed. London: 1743) 316. 
them in their temples, one beautiful image for each particular thing, they manifested the non-discursiveness of the intelligible world. Every image is a kind of knowledge and wisdom and is a subject of deliberation. And afterwards [others] deciphered [the image] as a representation of something else by starting from it in its concentrated unity, already unfolded and by expressing it discursively and giving the reasons why things are like this. ${ }^{4}$

This is how Marsilio Ficino commented on this passage:

The discursive knowledge of time is, with you, manifold and flexible, saying for instance, that time is passing and, through a certain revolution, connects the beginning again with the end... The Egyptian, however, comprehends an entire discourse of this kind by forming a winged serpent that bites its tail with his mouth. ${ }^{5}$

"Using an alphabet of things and not of words," wrote Sir Thomas Browne in the first half of the seventeenth century, "through the image and pictures thereof, they (the Egyptians) endeavoured to speak their hidden contents in the letters and language of nature." God created the world as symbols and images and the Egyptians merely imitated the creator. Their system of writing was held to be as original and natural as Adam's language which immediately translated God's creatures into words. ${ }^{6}$

Hieroglyphic writing, therefore, was held to be not only a system of communication but also and above all a codification of sacred knowledge and divine wisdom. It was both natural and cryptic, whereas alphabetic writing was held to be both conventional and clear. Hieroglyphs were invented by the Egyptians for the purposes of mystery, for the transmission of esoteric knowledge, the Alphabet was invented for the purposes of communication, administration and documentation.

${ }^{4}$ Plotinus, Enneades V, 8, 5, 19 and V, 8, 6, 11, quoted after Moshe Barash, Icon. Studies in the History of an Idea, New York 1992, 74f. . Cf. A. H. Armstrong, "Platonic Mirrors," Eranos 1986 vol. 55 (Frankfort: Insel, 1988) 147-182. On Plotinus' concept of non-discursive thinking see Richard Sorabji, Time, Creation and the Continuum. Theories in Antiquity and in the Early Middle Ages (Ithaca, NY: Cornell UP, 1983) 152f.

${ }^{5}$ Marsilio Ficino, In Plotinum V, viii, = P.O. Kristeller, Supplementum Ficinianum. Marsilii Fïini Florentini philosophi Platonici Opuscula inedita et dispersa, 2 vols. (Florence: Olschki, 1937-45 repr. 1973) 1768, quoted after Dieckmann, Hieroglyphics, 37. Cf. Edgar Wind, Pagan Mysteries in the Renaissance (New Haven: Yale UP, 1958) 169ff.; M. Barasch, Icon, 75.

${ }^{6}$ Cf. Umberto Eco, La ricerca della lingua perfetta nella cultura europea (Rom and Bari: Laterza 1993). Cf. Aleida Assmann, "Die Weisheit Adams," Weisheit, ed. Aleida Assmann (Munich: Fink, 1991) 305-324. 
This reconstruction of Egyptian grammatology became more complicated when Giordano Bruno and others introduced an evolutionary perspective. For Giordano Bruno, hieroglyphs were the original script, whereas alphabetic writing was a later invention.

.... the sacred letters used among the Egyptians were called hieroglyphs ... which were images ... taken from the things of nature, or their parts. By using such writings and voices, the Egyptians used to capture with marvellous skill the language of the gods. Afterwards when letters of the kind which we use now with another kind of industry were invented by Theuth or some other, this brought about a great rift both in memory and in the divine and magical sciences. ${ }^{7}$

Bruno refers to Plato's famous passage in Phaedrus. ${ }^{8}$ Plato is opposing writing (in general) against oral communication, not phonographic writing against picture writing. But Bruno's reading of the tale opens a highly interesting view on the mnemotechnical properties of hieroglyphs. ${ }^{9}$ Plato warns that writing will destroy memory because it makes people rely on external signs instead of interior insight and recollection. In Bruno's interpretation, the king is afraid that Theuth's invention of phonographic letters will destroy the Hermetic knowledge stored in the hieroglyphic images. Not "memory" as a human faculty, but the ars memoriae of the hieroglyphic system will be destroyed by the invention of letters.

Plato, as a matter of fact, thinks of "alphabetic writing" when he speaks of grammata. In his later dialogue Philebus (18b), he returns to the myth of Theuth as the inventor of writing. Here, he makes it

7 Giordano Bruno, De Magia (Opera Latina III, 411-412), quoted after Frances Yates, Giordano Bruno 263. The connection between hieroglyphics and magic is provided by the church historian Rufinus who reports that the temple at Canopus was destroyed by the Christians because there existed a school of magic arts under the pretext of teaching the "sacerdotal" characters of the Egyptians (ubi praetextu sacerdotalium litteranum (ita etenim appellant antiquas Aegyptionum litteras) magicae artis erat paene publica schola; Rufinus, Hist.eccles. XI 26).

${ }^{8}$ Phaedrus 274c-275d cf. Jean Pierre Vernant, "Le travail et la pensée technique," in J.P. Vernant, Mythe et pensée chez les Grecs: études de psychologie historique (Paris: F. Maspéro, 1971) 16-43. Cf. Plato, Philebus 18b-d, where the 'letters' of Theuth resemble those of the Greek alphabet and refer to sounds, thus being phonographic instead of hieroglyphic.

9 On hieroglyphics and memory cf. Francis Bacon, Advancement of Learning (London, 1605) II, XV, 3: "Embleme deduceth Conceptions Intellectuall to images sensible, and that which is sensible, more forcibly strikes the memory, and is more easily imprinted, than that which is Intellectuall". 
perfectly clear that we are dealing with alphabetic writing. Theuth's discovery concerns the distinction between the infinite variety of sounds and the finite number of what we call "phonemes". This discovery enables him to invent letters (stoicheia) for each of those phonemes. ${ }^{10}$ Bruno obviously combines the two versions of the myth in making Theuth the inventor not of writing in general, but of the alphabet in particular. He knew that the Egyptians used Hieroglyphs as a pictorial script referring not to sounds but to things - signa rerum, non autem sonorum. Thus, Plato's myth could only refer to the invention of a second script, the alphabet.

This evolutionary interpretation of Egyptian writing was taken up 150 years later by William Warburton, an Anglican bishop, aristocrat and homme de lettre. He was not only a friend of Alexander Pope and edited the works of Shakespeare but also published a monumental work in nine books and three volumes on The Divine Legation of Moses (1738-1741).

Warburton contended that Hieroglyphs were original and that alphabetic letters were only a secondary invention. But he also wanted to show, that originally, Hieroglyphs had nothing to do with mystery, esoteric knowledge and Hermeticism. These functions and qualities were only developed within the hieroglyphic system when it was integrated alongside with alphabetic letters into the system of digraphia. His argument was simple and reasonable. He looked into the origins of other writing systems and found that no original writing was ever invented for the sole purpose of secrecy. Warburton based his demonstration on Chinese and Mexican scripts, using whatever information was available in his time from missionaries and travellers. The Egyptian method of figurative writing by picturing "things" and using the properties of things in order to denote undepictable meanings requires a vast knowledge of natural history. This ingenious observation of Warburton explains the striking analogies between Horapollo's interpretations of hieroglyphics on the one hand and codifications of ancient natural sciences such as Aelianus, Pliny, and the Physiologus on the other. ${ }^{11}$ Unlike all other scripts, the Egyptian

\footnotetext{
${ }^{10}$ See Robert Eisler, "Platon und das ägyptische Alphabet", in: Archiv für Philosophie XXXIV, 1922, 3-13.

${ }^{11}$ Cf. Erik Iversen, The Myth of Egypt and its Hieroglyphs in European Tradition (1961), 2nd ed., Princeton, 1993; 48: "The relations between sign and meaning were according to Horapollo always of an allegorical nature, and it was always established by means of exactly the same sort of 'philosophical' reasoning which we find later in the Physiologus and the bestiaries of the Middle Ages."
} 
hieroglyphs remained a "Dingschrift" (signa rerum) and thus a codification of cosmological and biological knowledge. Other writing systems lost this epistemological connection with the visible world and turned into purely conventional codes.

After this demonstration of origins, the ground is prepared for the next step: the question of "how hieroglyphs came to be used to conceal knowledge." Again, Warburton's explanation is most ingenious. Precisely because the Egyptian script did not take the common course from picture to letter, it became complex and developed into polygraphy. While other civilizations changed their script according to the general gravitation from pictures to letters, the Egyptians kept their ancient pictorial system alongside with their new alphabetic script. Yet Warburton's reconstruction is even more complex. He refers to Porphyry and Clement of Alexandria and combines their seemingly divergent descriptions in order to arrive at a system of tetragraphy. Porphyry writes in his Life of Pythagoras that Pythagoras during his long sojourn in Egypt became initiated into the three kinds of Egyptian writing, the Epistolographic, the Hieroglyphic and the Symbolic script. The Hieroglyphs denoted their meaning by imitation (kata mimesin), the Symbolic script by enigmatic allegories (kata tinas ainigmous). Clement describes the curriculum of an Egyptian pupil. First, he learns the Epistolic writing, then proceeds to the Sacerdotal script, and only exceptionally arrives at Hieroglyphics which is the last, most difficult, and most accomplished script. Hieroglyphs signify either through "elementary letters" (dia ton proton stoicheion) or through symbols of which there are three kinds: mimetical (kata mimesin), tropical (tropikos) and allegorical (or enigmatic) ones. The mimetical symbols directly depict what they signify, the tropical symbols use several metaphorical or metonymical ways of signification and the allegorical symbols are enigmatic. For modern egyptology, it is perfectly easy to correlate both Porphyry's and Clement's descriptions with the late Egyptian situation. They are referring to what we call Demotic, Hieratic and Hieroglyphic. For Warburton, however, these data were not yet available. Warburton thinks that each of the two authors is omitting a script that the other one mentions. Porphyry omits Clement's "Sacerdotal" writing, Clement omits Porphyry's "symbolic" script. Thus, Warburton arrives at a system of tetragraphy: Epistolic, Sacerdotal, Hieroglyphic, and Symbolic. Two of them he thinks to have been iconic (Hieroglyphic and Symbolic), the other two alphabetic (Epistolic and Hieratic). Two belong to the public domain: Hieroglyphic and Epistolic, and two to the domain of the sacred and secret: Symbolic and Hieratic. 


\section{Function}

\begin{tabular}{|c|c|c|c|}
\hline \multirow{3}{*}{ System } & & $\begin{array}{l}\text { public domain } \\
\text { (official script) }\end{array}$ & $\begin{array}{l}\text { secrecy } \\
\text { (priestly script) }\end{array}$ \\
\hline & pictures & Hieroglyphs & Symbolic \\
\hline & letters & Epistolic & Hieratic \\
\hline
\end{tabular}

Warburton thinks that Clement is describing not the curriculum of an Egyptian pupil but the development of Egyptian writing: starting with Demotic, developing into Hieratic, and ending up with Hieroglyphic. Therefore, he thinks it necessary to correct Clement in this point and to invert this sequence. In the history of writing, Hieroglyphic came first, then Sacerdotal and finally Epistolic and Symbolic. By turning Clement's pupil into a people, Warburton develops a theory of cultural evolution based on grammatology which became of utmost importance for the 18th century. Within this grammatological reconstruction of human evolution, the invention of alphabetic writing constituted a revolutionary step.

For Warburton, this event occurs with the invention of epistolic writing which he takes to be alphabetic. This invention occurred somewhere midway in the long history of Egyptian civilization. A secretary of Pharaoh made this discovery which originally was used only for the private correspondence of the king. Warburton refers like Bruno to Plato's Phaedrus. ${ }^{12}$ Like Bruno, Warburton thinks that Plato's objections against writing do not concern memory but memorized knowledge. In the same way as Bruno, Warburton interprets hieroglyphic writing as a kind of mnemotechnique. He points out that hieroglyphs presuppose a vast amount of knowledge about the nature of those things that are used for signs. Since virtually all existing things are used for signs, this knowledge amounts to a veritable cosmology and the hieroglyphic system amounts to a veritable ars memoriae.

12 Phaedrus 274c-275d cf. Jean Pierre Vernant, "Le travail et la pensée technique," in J.P. Vernant, Mythe et pensée chez les Grecs: études de psychologie historique (Paris: F. Maspéro, 1971) 16-43. Cf. Plato, Philebus 18b-d, where the 'letters' of Theuth resemble those of the Greek alphabet and refer to sounds, thus being phonographic instead of hieroglyphic. 
Men's attention would be called away from things, to which hieroglyphics, and the manner of explaining them, necessarily attached it, and be placed in exterior and arbitrary signs, which would prove the greatest hindrance to the progress of knowledge. ${ }^{13}$

Thanks to the wisdom of their kings the Egyptians never gave up their systems of "thing-writing" and confined the new alphabet to the specific purposes of correspondence.

Following Warburton's reconstruction, we are now approaching the time when Moses "was brought up in all the wisdom and sciences of the Egyptians" (Acts 7:22) and when with Moses and revelation the problem of idolatry and iconoclasm arose. At Moses' time, all four scripts were already in use. Moses, educated in all four kinds of Egyptian writing, had the choice which script to use in order to write down the Law. For this purpose, only a script was to be considered appropriate that was commonly accessible and aniconic in order to conform to the second commandment and to the task of making the Law known to all the people. The epistolic writing fulfilled both these requirements. Moses had just to purge the letters of all iconic traces. According to Warburton, the second commandment was explicitly directed against hieroglyphs because God had recognized that the use of hieroglyphic writing would necessarily lead to idolatry.

The second commandment prohibiting idol-worship has two different implications. ${ }^{14}$ It is mostly understood in the sense that God must not be represented because he is invisible and omnipresent. ${ }^{15}$ But as Warburton correctly points out, the same commandment also prohibits the making of "any graven images, the similitude of any figure, the likeness of male or female, the likeness of any beast that is on the earth, the likeness of any winged fowl that flieth in the air, the likeness of anything that creepeth on the ground, the likeness of any fish that is in the waters beneath the earth" (Deut 4:15-18, Warburton's translation). Warburton's interpretation emphasizes the anti-Egyptian meaning of the prohibition of idolatry. It is the exact "normative inversion" of the very fundamental principles of Egyptian

13 William Warburton, The Divine Legation of Moses Demonstrated on the Principles of a Religious Deist, from the Omission of the Doctrine of a Future State of Reward and Punishment in the Jexish Dispensation, 1738-1741, vol. 2, 428.

${ }_{14}$ Cf. M. Barasch, Icon.

${ }^{15}$ Cf. M. Halbertal, A. Margalit, Idolatry, Cambridge, Mass., 1982, 37-66 ("Idolatry and Representation"). 
writing, thinking, and speaking: "Do not idolize the created world by $<$ hieroglyphic > representation." The second commandment is the rejection of hieroglyphic knowledge and memory because it amounts to an illicit magical idolization of the world.

According to Warburton, idolatry is an outgrowth of hieroglyphic writing and thinking. It is a specifically Egyptian phenomenon because Egypt is the only civilization that retained the pictorial character of its writing and resisted the usual tendency towards abstraction. The proof of this is to be seen in the fact that "brute-worship," the worst form of idolatry, occurs only in Egypt. Warburton goes on to delineate different stages in the development of idolatry. In the first stage, the figures of animals are just signs which stand for some tutelary gods or deified hero-kings. "This truth Herodotus seems to hint at in Euterpe, where he says, the Egyptians erected the first altars, images, and temples to the gods, and carved the figures of animals on stones." 16 The second stage is reached when these figures are worshiped on their own instead of being simply "read" as signs for the various gods. This stage was reached during Moses' time, and that is the reason why the second commandment prohibits the making of images, not the worship of the things themselves. The worship was still directed towards the image. For the same reason the Hebrews made a Golden Calf as a substitute for Moses whom they believed to be dead.

The Egyptians only later fell into worshiping the beasts themselves. This is the last stage of "idolitis." The priests welcomed and fostered this development because it protected the gods even more efficiently against being found out. The priests, at least those who passed the most advanced initiations, knew the truth about the gods that they were only deified kings and lawgivers, and they had every reason to make this origin of the gods invisible and to keep it a secret. The representation of these deified mortals in the form of animals was a first step towards making their origin invisible. It became even more efficient when the people turned to worship the representations instead of the represented. But absolute invisibility was reached when the animals themselves came to be worshiped. The animals were the perfect concealment for the gods.

${ }^{16}$ Herodotus, Hist. II, ch. 4; cf. Alan B. Lloyd, Herodotus Book II. Commentary 1-98 (Leiden: Brill, 1976) 29-33. Warburton interprets the word " $z o a$ " which means "figure, image" (Liddle-Scott-Jones, p.760 a s.v. zoon II) as "animals." 
According to Warburton this is the meaning of a fable which Diodorus and Ovid tell about Typhon. ${ }^{17}$ Typhon is seen as the personification of inquisitiveness and impious curiosity, the very character that is so dangerous for the pseudo-gods. The fable tells how the gods fled to Egypt before Typhon and hid there in the shape of animals. Typhon is the Greek equivalent of the Egyptian god Seth, who is actually represented in the Egyptian texts as threatening the gods with the sacreligious discovery of their secrets. According to the Egyptians, the secret of the gods is not the Euhemeristic concept of their mortal past, but even this is not totally abstruse. The paradigmatic secret, in Egypt, is the corpse of Osiris which must by all means be protected against the assaults of Seth. The role of Seth as the potential discoverer and violator of the corpse of Osiris was extended in the Late Period to the notion of a general menace to all of the secrets of all the gods. There was generally an enormous increase of secrecy in the Egyptian cults during the Late Period. This is quite natural under the conditions of foreign rule. Since this was the Egypt which the Greek experienced and described, the emphasis laid on secrecy and the fear of inquisitive curiosity becomes quite understandable.

Warburton derives two Egyptian specialties from their writing system. One is "brute-worship," the other specialty is the interpretation of dreams. According to Artemidorus there are two kinds of dreams: "speculative" (theorematikos) dreams and "allegorical" ones. ${ }^{18}$ The "speculative" dreams are just images of what they signify. They correspond to the "curiological" hieroglyphs. By contrast, the allegorical dreams need to be deciphered. The Egyptians were the first interpreters of dreams because they were accustomed to the methods of deci-

17 See Diodorus, Bibl. I 86; Ovid, Met. V $321 \mathrm{ff}$; Plutarch, De Iside et Osiride, c. 72; Theodor Hopfner, in his commentary on Plutarch, De Iside II, Prague 1941, 264 gives the following additional refernences: Pindar frg 68 apud Porphyrius, De abstin. III 16; Nigidius Figulus, Sphaera Graecan., 122/25 Sw.; Josephus Flavius, Contra Ap. II,11; Apollodorus, Bibl. I 41; Hyginus, Astronom. II, 28; Nicandrus apud Antonin. Liberal. 28. Ovid, Metamorph. Buch III, Nr.5, see also Lothar Störk, "Die Flucht der Götter”, in: Göttinger Miszellen 155, 1996, 105-108. In Diodorus I, cap. 86, the gods are hiding in animal shapes for fear, not of Typhon but of human beings. Afterwards, the gods declared the animals sacred in whose shape they had been hiding.

${ }^{18}$ For Warburton's theory of dreams and hieroglyphs see Aleida Assmann, "Traum-Hieroglyphen von der Renaissance bis zur Romantik", in: G. Benedetti, E. Hornung, eds., Die Wahrheit der Träume, Eranos NF 6, Munich 1997, 119-144, esp. 123-126. 
pherment and could just "read" the dreams where others guessed and puzzled. But the art of oniromancy could only develop when hieroglyphics became sacred "and were made the cloudy vehicle of their theology." 19 This must have happened, however, before the time of Joseph. ${ }^{20}$ The development of symbolic hieroglyphics as a sacred cryptography must already have been developed in Joseph's time because oniromancy, a subdiscipline of cryptography and decipherment, was already in use. Four hundred years later, in Moses' time, the use of hieroglyphs had already given rise to a general idolization of "things" to such a degree that God had to explicitly prohibit the use of hieroglyphs in the second commandment. But it is also clear that the Egyptians had not yet reached the stage of brute-worship because the Hebrews made a Golden Calf instead of worshiping a living bull when they fell back on Egyptian customs.

Idolatry and brute-worship are aberrations of the human mind that were implied in the hieroglyphic writing, because this script turned and fixed the attention on the things of the world. Warburton explains idolatry as a sickness of writing, in the same way as more than 100 years later Friedrich Max Mueller explains myth as a sickness of language. ${ }^{21}$ Both idolatry and mythology result from a literalistic misunderstanding of metaphor.

Half a century after the first publication of Warburton's Divine Legation of Moses, Moses Mendelssohn brought grammatology and theology in an even closer connection in his booklet ferusalem where he concentrates on the theological implications of writing. "Methinks", he writes, "the changements of writing during the different periods of culture have a big share in the revolutions of human cognition in

19 Warburton, Divine Legation vol. 2, 458.

${ }^{20}$ It is typical of Warburton's way of argumentation that he forms this brilliant insight into the relation between oniromancy and hieroglyphic writing (which will become so important in the work of Sigmund Freud) in the context of a chronological demonstration, thus forgoing the obvious possibility of interconnections between the dream-book of Artemidoros and hieroglyphic theories of Hellenism.

21 "So oft man nun ein Wort, das zuerst metaphorisch gebraucht wurde, anwendet, ohne sich über die Schritte, die von seiner ursprünglichen zu seiner metaphorischen Bedeutung hinführten, ganz im Klaren zu sein, liegt die Gefahr der Mythologie nahe; so oft diese Schritte vergessen und künstliche Schritte an ihre Stelle gesetzt werden, haben wir Mythologie oder wenn ich so sagen darf, krankgewordene Sprache", F. Max Müller, Die Wissenschaft der Sprache, Leipzig 1892, II, 434-36, quoted after Maurice Olender, Die Sprachen des Paradieses, Frankfurt 1995, 90. 
general and of their various religious convictions and conceptions in particular. ${ }^{22}$ Mendelssohn, too, assumes the first script to be pictorial and imagines it as a kind of moralizing zoography, where "the lion stands for braveness, the dog for fidelity, the peacock for fierce beauty". 23 "If people, he writes, want to use the things themselves or their images to denote concepts, there are no things more appropriate and significant for the denotation of moral qualities than animals. Every animal has its distinctive character and shows it immediately by its external aspect."" "Even the poet, when he wants to speak of moral qualities in metaphors and allegories, has recourse to the animal. Lion, eagle, bull, fox, dog, bear, worm, dove, all this speaks and the meaning strikes the eye". ${ }^{25}$

In the beginning, people think, speak and write in images; only later do they turn to thinking in arguments, speaking in prose and writing with letters. ${ }^{26}$ The danger of picture writing lies in the confusion of sign and signified. Thus, an innocent thing such as a mode of writing can degenerate and turn into idolatry. But, Mendelssohn adds, we must always be careful not to see everything through our home-made glasses and to call idolatry what fundamentally might be only writing. ${ }^{27}$ In order to avoid the pitfalls of idolatry, God had Moses write down his laws in alphabetic letters, not in pictorial hieroglyphs. But the law is in itself just another kind of writing and this third form of writing is to Mendelssohn's eyes the most appropriate form of transmitting religious conceptions. This is the function of the ceremonial Law. Rites are a kind of practical hieroglyphs. Francis

22 "Mich dünkt, die Veränderung, die in den verschiedenen Zeiten der Kultur mit den Schriftzeichen vorgegangen, habe von jeher an den Revolutionen der menschlichen Erkenntnis überhaupt und insbesondere an den mannigfachen Abänderungen ihrer Meinungen und Begriffe in Religionssachen sehr wichtigen Anteil"-Moses Mendelssohn, Jerusalem, in: Schriften über Religion und Aufklärung, ed. Martina Thom, Berlin 1989, 422f.

${ }^{23}$ Mendelssohn, 426.

24 Mendelssohn, 430.

25 Mendelssohn, 430.

${ }^{26}$ See for this idea already F. Bacon, The Advancement of Learning (1605; Oxford 1974, 98: "as hieroglyphics were before letters, so parables were before arguments; and nevertheless now and at all times they do retain much life and vigour, because reason cannot be so sensible, nor examples so fit."). The interpretation of the discourse on hieroglyphs in terms of cultural evolution and the assumption of a concrete thinking, speaking and writing in images preceding the formation of an abstract thinking=speaking=writing in letters and concepts is shared by authors such as Condillac, Diderot, Hamann and Herder.

${ }^{27}$ Mendelssohn, 432. 
Bacon had already associated hieroglyphs with gestures, in calling gestures "transitory hieroglyphs": "As for gestures, they are as transitory hieroglyphics, and are to hieroglyphics as words spoken are to words written, in that they abide not". ${ }^{28}$ By means of the ceremonial Law, God wanted to inscribe religious meaning in the everyday activities of people. ${ }^{29}$ The ritual writing serves as a kind of mnemotechnique preserving religious knowledge without leading either to idolatry as hieroglyphs do, or to dead abstraction as letters do. "We are lettrified beings (Buchstabenmenschen). Our whole nature depends on letters". ${ }^{30}$ The way of hieroglyphs leads to idolatry, the way of letters leads to "lettrification", to abstract speculation, but the Jewish way of halakha, the information of everyday life with religious meaning, preserves the chosen people from both forms of degeneration. ${ }^{31}$

What I find most interesting in this debate on hieroglyphs and letters is the correlation of media, epistemology and religion. In our century there have been similar debates on the implications of writing, connected with the names of Marshall McLuhan, Jack Goody and others. Eric Havelock coined the term "alphabetic revolution" which he interpreted as a Greek achievement leading to abstract thinking, logical reasonment, scientific research, technology and everythings else which shaped Western culture including monotheism and enlightenment. ${ }^{32}$ The 18th century did not go that far. Scholars of that time were operating within a far more restricted field of available data. Yet they were remembering what nowadays tends to be forgotten: the fact that the invention of the alphabet (in the sense of non-pictorial signs relating exclusively to sounds) was not a Greek but

${ }^{28}$ For Bacon's interpretation of gestures as der transitory Hieroglyphs see Detlef Thiel, "Schrift, Gedächtnis, Gedächtniskunst. Zur Instrumentalisierung des Graphischen bei Francis Bacon", in: J.J.Berns, W. Neuber (eds.), Ars memorativa, Tübingen 1993, 170-205, esp. 192f.; Peter Burke, Vico, Philosoph, Historiker, Denker einer neuen Wissenschaft, Frankfurt 1990 (engl. 1985), 50.

29 "Mit dem alltäglichen Tun und Lassen der Menschen sollten religiöse und sittliche Erkenntnisse verbunden sein": Mendelssohn, 437.

30 "Wir sind Buchstabenmenschen. Vom Buchstaben hängt unser ganzes Wesen ab.": Mendelssohn, 422.

${ }^{31}$ Mendelssohn's criticism of alphabetic writing comes close to a line of argumentation which has been dealt with by Aleida Assmann as "Exkarnation", see her article "Exkarnation. Über die Grenzen zwischen Körper und Schrift", in: J. Huber, A.M.Müller (Hgg.), Raum und Verfahren, Zürich und Basel 1993, 133-156.

${ }^{32}$ On these theories see Aleida and Jan Assmann, "Schrift - Kognition - Evolution. Eric A. Havelock und die Technologie kultureller Kommunikation", in: E. A. Havelock, Schriftlichkeit. Das griechische Alphabet als kulturelle Revolution, Weinheim 1990 , 1-35, with extensive bibliography. 
a Semitic achievement and that it was in fact ultimately derived from Egyptian hieroglyphs. The idea to correlate this grammatological revolution with an iconoclastic rejection of images, with monotheism and what Freud called a progress in intellectuality (Fortschritt in der Geistigkeit) is at least as interesting a phantasy as its modern correlation with logical thinking, democracy and other allegedly Western achievements. In the same way as monotheism could be regarded as an exodus out of the cosmological shelter (or prison-house) of natural religions or "cosmotheism", alphabetic writing came to be regarded as an exodus out of the sensual involvement in the world of visible forms. Warburton and Mendelssohn were right: revelation could only take place in a realm of signs, not of pictures. 